$10(1)(2021) 49-58$
Unnes Science Education Journal
Attps://journal.unnes.ac.id/sju/index.php/usej

\title{
The Potential of Electronic Media Integrated Islamic Values on Stu- dents' Motivation and Creative Thinking Ability
}

\author{
Ucca Swasti Praptiwi ${ }^{\bowtie}$, Agus Yulianto, Ellianawati Ellianawati
}

DOI: http://dx.doi.org/10.15294/usej.v10i1.42340

Science Education Study Program, Postgraduate, Universitas Negeri Semarang, Indonesia

\section{Article Info}

Submitted 3 November 2020 Revised 28 December 2020 Accepted 17 February 2021

\section{Keywords}

electronic comics, problem based learning, islamic values, student learning motivation, and creative thinking skills

\begin{abstract}
This research is a preliminary study regarding the teacher's description of learning, student learning motivation, students' creative thinking skills, and the need for developing electronic comic learning media based on integrated problem based learning Islamic values at SMPN 3 Watumalang. This research uses a descriptive method. This study's subjects were 44 students of class VIII and teachers of science subjects at SMPN 3 Watumalang. The research was conducted from October to November 2020. The data collection instruments were questionnaires, interview guidelines, and creative thinking skills test questions. The results of interviews with students indicated that the students' intrinsic motivation was still low. The ability to think creatively is still lacking, with a percentage of $42.8 \%$. In the elaboration indicator, most students answered correctly, while in the originality indicator, students were less careful in answering, and only $14.3 \%$ of students could answer correctly. Based on the questionnaire analysis results, electronic comic learning media based on problem based learning integrated Islamic values as an alternative media for learning media on vibrations, waves, and sounds in everyday life are needed for development with a percentage of $64 \%$. The use of electronic comics is expected to increase student motivation and creative thinking skills.
\end{abstract}

\section{How to Cite}

Praptiwi, U. S., Yulianto, A., Ellianawati, E. (2021). The Potential of Electronic Media Integrated Islamic Values on Students' Motivation and Creative Thinking Ability. Unnes Science Education Journal, 10(1), 49-58.

$\triangle$ Correspondence Author:

E-mail: uccaswasti012@students.unnes.ac.id 


\section{INTRODUCTION}

Advances in technology make it easier for everyone to access the internet. This is one of the characteristics of the 21 st century, which can affect the importance of digital and technological literacy in learning activities. Learning activities can take advantage of information and communication technology such as the internet and smartphones. Based on data from the Indonesian Internet Service Providers Association (APJII) in 2018, the highest internet users total $78.50 \%$ aged 13 to 18 , namely junior high school age. This makes learning media using the internet that can attract students to learn. Junior high school students are still at a significant period to be considered in their growth and development stage. Learning media that are effective and by the stages of child development are comics (Rina et al., 2020).

Science comics have developed rapidly as webcomics or electronic comics, or digital comics that are easily accessible to students (Tribull, 2017). Based on the study results, students are less interested in reading textbooks and more comfortable reading material presented in comic form (Shekarbaghani, 2016; Tribull, 2017). Visually comics are great for students enjoying visual art (Ledbetter et al., 2016; White, 2017). The superiority of the visual nature of comics in education is that they create a sense of comfort, a way to read comics that are not bound by time, and students can communicate directly with characters so that it is as if students can become part of the comic narrative (Derbel, 2019).

Comics present a story arranged sequentially using text and images that have potential in education (Scavone et al., 2019). Comics can explain narratives concisely and efficiently (Ronan \& Czerwiec, 2020), helping students understand learning material (Ledbetter et al., 2016; Roswati et al., 2019). Comics can also increase motivation and interest in learning and help students understand the subject matter (Kim et al., 2017; Tribull, 2017; Affeldt et al., 2018; Puspitarini \& Hanif, 2019).Learning using comics can provide alternative views and help students solve problems (Balim et al., 2016). Problem based learning through comics can be used as a teaching and learning strategy by providing scenarios related to everyday life, converted into comic concepts (Jamal et al., 2019).

Learning activities by applying the problem based learning method is essential, but integrating Islamic values in learning is also crucial. Science learning in schools is still minimally in- tegrated with Islamic values, be it a model, method, or learning approach. Research on integrating Islamic values and teaching materials that support learning objectives has not been done much (Purwati et al., 2018). Electronic comic media based on integrated problem based learning of Islamic values is essential to development because it is an alternative teaching medium in the form of comics accessed through the online webtoon application and presents problems in everyday life that are integrated with Islamic values in the form of al-Quran verses.

Problem based electronic comics can connect learning material with information in the real environment through problems in comics. Students can build learning experiences in solving problems and learning effectively (Yew \& Goh, 2016). Comics connected to everyday life can help a more intense learning experience and connect students and science questions (Affeldt et al., 2018). The problems presented can foster students' creative ideas to solve them (Fery et al., 2017)but unable to apply them in solving real life problems. Therefore, this study aims to improve primary school students' mathematical literacy through problem-based learning and direct instruction. In addition, the research was conducted to determine whether there are differences in the increase in literacy mathematical among students who received problem-based learning and direct instruction in primary schools located in urban areas, transition, and villages, as well as whether there is an interaction effect between the model of learning by location category of the school toward mathematical literacy skills of primary school students. The study was conducted in the academic year 2015 to 2016 in the fifth grade public primary schools in Bandung with three categories of school location (rural, city and county transition. Students can find out the problems in student life, especially in the material of vibrations, waves, and sounds in everyday life. For example, the problems presented are allergies to the larynx, which can cause pain in the vocal cords, ringing in the ears due to ear cleaning, bomb explosions that cause resonance, application of sound reflection cases of noise that occur at airports. These problems can make students know the problems: vibrations, waves, and sounds in everyday life.

Electronic comics are also integrated with Islamic values in learning, namely by including relevant Qur'anic verses into learning material (Nuryantini, 2018). Examples of the integration of Islamic values in the material of vibrations, waves, and sounds in everyday life such as sa'i 
worship, which is very passionate with the concept of vibration, flood waves that are with the idea of waves in Al-Qur'an Surah Hud verse 43, the concept of resonance in Human heart who often dhikr in Surah Al-Anfal verse 2 and the sound reflection which is served with the verses of Al-Quran Surah An Naml verse 16. This media is expected to motivate students in learning and improve students' creative thinking skills.

The novelty in this research is to see the potential for the development of electronic comics made in webtoon lines that discuss daily problems and are integrated with Islamic values. Andro webcomics can be used as an alternative to teacher teaching materials that attract students' attention to learning, are easy to test, and display attractive illustrations using simple language (Lesmono et al., 2018). Comics based on electronic problem based research problems in research focused on looking at student learning motivation and students' creative thinking abilities. Comics are the best way to encourage children to think creatively (Koutníková, 2018). Electronic comics are also integrated with Islamic values in the form of al-Quran verses in the material of vibrations, waves, and sounds in everyday life that has not been studied. Natural science learning integrated with Islamic values can improve students' understanding of material learning (Nurdyansyah \& Arifin, 2018).

Based on this background, a preliminary study on electronic comic media development based on learning problems based on integrated Islamic values was held. The research objective is to determine the potential of learning if developing electronic comic media based on problem based learning integrated with Islamic values as a preliminary research study, including learning by teachers, student motivation, students' creative thinking skills, and the need for electronic comic media development. Based on problem based learning integrated Islamic values.

\section{METHOD}

This type of research is a descriptive study that is to describes the current situation. Descriptive research was conducted by focusing on the problem when the research was carried out and then presenting it (Sudjana, 2005). This study's subjects were 44 students of grade VIII and science subjects teachers at Junior High School 3 Watumalang. The study was conducted from October to November 2020.

The data instruments were questionnaires, new interviews, and creative thinking skills test questions. The distribution of questionnaires for learning media needs based on learning problems based on Islamic values integration was carried out using google form. Interviews were conducted directly with science teachers, which contained several questions that could obtain initial information about problems in science learning, the learning that was carried out, and students' learning motivation. Interviews were also conducted directly with 11 students, which contained several questions about students' learning motivation. Students' creative thinking ability is done by giving essay questions in the form of tests of creative thinking abilities. The data obtained were then analyzed quantitatively.

\section{RESULT AND DISCUSSION}

The preliminary study in this research includes teachers' learning, student learning motivation, students' creative thinking skills, and the need for developing electronic comic learning media based on problem based learning integrated with Islamic values, especially in the material of vibrations, waves, and sounds in everyday life.

Science Learning Process

The teacher's analysis of the learning process was obtained from interviews with science teachers and a questionnaire on student needs. The results of interviews with science teachers regarding science learning that have been carried out by teachers are presented in Table 1.

Based on Table 1, learning has not applied various learning media, so students are less motivated in learning. Student motivation depends on the teacher providing learning material (Wood, 2019). It is necessary to have learning activities that make students motivated in learning activities. Learning has implemented the problem based learning method because it is considered to make it easier for students to understand the material being taught (Bayrak \& Gürses, 2020). Problem based learning through comic media is a teaching and learning strategy by providing scenarios related to everyday life, converted into comic concepts (Jamal et al., 2019). Problem based learning enables students to play an active role in problem solving in learning activities (Balim et al., 2016)in which events from daily life are presented as interesting scenarios, is one of the active learning approaches that encourages students to self-direct learning. Problem based learning, generally used in higher education, requires students to use high end thinking skills in learning environments. In order to use effectively for secondary students, concept cartoons can be integrated to problem based learning environment. Concept cartoons 
Table 1. Results of interviews regarding the science learning process

\begin{tabular}{|c|c|}
\hline Question Component & Answer \\
\hline $\begin{array}{l}\text { Initial information } \\
\text { about teachers and } \\
\text { students on science } \\
\text { learning. }\end{array}$ & $\begin{array}{l}\text { The teacher conveys learning material with more theories than activities } \\
\text { that trigger student activities. Teachers use KIT or teaching aids according } \\
\text { to the learning material. Lessons often use instructional videos to make } \\
\text { students feel happy and not bored with the material being taught. Learn- } \\
\text { ing outcomes are generally incomplete because they are influenced by low } \\
\text { motivation and the inadequate availability of human resources. }\end{array}$ \\
\hline $\begin{array}{l}\text { Teacher responses } \\
\text { and teaching process } \\
\text { before using electronic } \\
\text { comic media based on } \\
\text { problem based learn- } \\
\text { ing. }\end{array}$ & $\begin{array}{l}\text { Teachers have never used electronic comic media based on problem based } \\
\text { learning, but they often use problem based learning for learning methods. }\end{array}$ \\
\hline $\begin{array}{l}\text { Barriers and expec- } \\
\text { tations in science } \\
\text { learning. }\end{array}$ & $\begin{array}{l}\text { The obstacles in learning science are students busy themselves when their } \\
\text { focus has decreased, students who sometimes destroy teaching media, and } \\
\text { low student motivation. Students find it difficult to learn science because } \\
\text { they think the material is too much and physics symbols are difficult for } \\
\text { students to understand. The hope is that learning media can be used in } \\
\text { learning and motivate students to learn. }\end{array}$ \\
\hline $\begin{array}{l}\text { Teachers' knowledge } \\
\text { about problem based } \\
\text { learning and learning } \\
\text { that is integrated with } \\
\text { Islamic values. }\end{array}$ & $\begin{array}{l}\text { Problem based learning is often applied in learning because students eas- } \\
\text { ily understand the material associated with daily life. Students are easily } \\
\text { conditioned if given a problem to find a solution. However, Islamic values } \\
\text { have not been implemented, and not understand this. }\end{array}$ \\
\hline
\end{tabular}

provide alternative views and help students at problem solving stage. So, in this study the effects of concept cartoons and problem based learning on students' inquiry learning skill perceptions and levels of relating knowledge with daily life were examined. Two experiment groups and one control group were formed and pre test-post test control group quasi experimental design was used in this research. During four weeks experimental practice, courses were continued with concept cartoon integrated problem based learning in experiment group 1 while only problem based learning was used in experiment group 2 and science program activities was used in control group. 553 sixth grade students (13-14 age group.

Student interest in science learning has the highest percentage in the medium category, as shown in Figure 1. Student interest in science learning is high, namely as much as $33 \%$, moderate as much as $63 \%$, and $4 \%$ of students have less interest in science learning. Students consider science difficult before studying the learning material. When science learning progresses, students respond to the teacher's learning when the material is considered easy. Students are interested in a specific topic and are interested in learning it (Bathgate \& Schunn, 2017). When the material presented to students is difficult, they still try to respond to the material given well. When students experience this, it is called situational interest, which occurs because of a direct response from the environment (Mills et al., 2020). There needs to be learning activities that can increase student interest in learning. Learning media can function as a tool to stimulate student interest in learning to improve student learning motivation (Puspitarini \& Hanif, 2019).

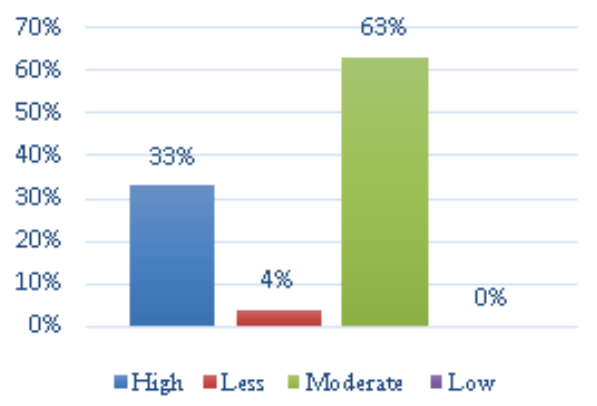

Figure 1. Student interest in science learning

Teaching materials used by teachers when delivering learning materials are as shown in Figure 2. Teachers often give learning materials using science books published by the government. Teachers need to be able to make teaching materials tailored to the circumstances of students and schools. The hope is that students easily understand the learning material. There are challenges 
for teachers to create quality teaching materials (Prins et al., 2018). The accuracy, application, and variety of teaching materials are crucial to note (Kahraman \& Koray, 2020). The use of teaching materials in learning aims to support the learning process to gain an understanding of concepts with meaningful learning activities (Mamolo, 2019). Internet based teaching materials can increase student interactivity and motivation to build meaningful knowledge (Korur et al., 2016).

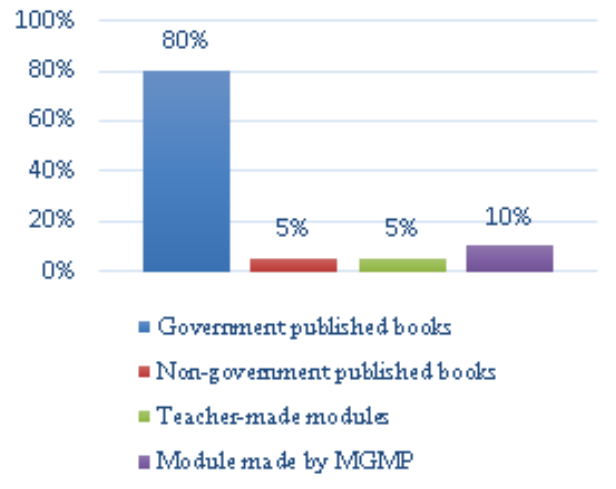

Figure 2. Teaching materials used by teachers in science learning

Besides teaching materials that support learning activities, school facilities also play an essential role in supporting learning activities. The available school facilities have not been able to support learning activities optimally. Particularly for the facilities that support science learning activities, most of the facilities are damaged and have not been repaired. These facilities are not always used in learning but are used only when needed.

Student's Motivation to Study

Motivation to learn plays an essential role in giving passion, enthusiasm, and pleasure in learning. Students who have high motivation and energy to carry out learning activities can ultimately achieve better achievements (Salta \& Koulougliotis, 2020). Motivation consists of intrinsic motivation and extrinsic motivation (Puspitarini \& Hanif, 2019). Intrinsic motivation comes from students, for example, the desire to gain knowledge, the urge to learn, and the desire to achieve learning goals (Bathgate \& Schunn, 2017). Extrinsic motivation comes from outside the student, for example, a learning environment that supports learning activities, fun learning companions, and learning activities that attract students' attention.

The motivational indicators used in this study are the desire and desire to succeed, the encouragement and need for learning, the hopes and aspirations of the future, the appreciation in learning, the interesting activities in learning and the existence of a conducive learning environment, a student can learn well (Uno, 2016). Based on the results of interviews with students directly, extrinsic motivation is more than intrinsic motivation.

The teacher realizes that student motivation in learning is very influential in student participation in the learning process. The development of student interest is also significant because it relates to participation in learning, learning outcomes, and student academic achievement (Mills et al., 2020; Wood, 2019). The teacher implements learning activities by providing rewards such as additional points of activity. The indicator of learning motivation that plays a role is the recognition of learning. Students are interested in taking an active part in learning activities because of this award. Students feel happy and motivated when they use interesting learning methods and media on the indicators of exciting learning activities. On the indicators and the existence of a conducive learning environment, allowing a student to learn well, students are more motivated if the learning environment is relaxed and easily understood. Extrinsic motivation plays a role here, which requires more effort to achieve it than intrinsic motivation. If there are no additional points for appreciation, students can lose their motivation to learn (LIbao et al., 2016).

Intrinsic motivation that exists in students is still low. Intrinsic motivation does not require external stimulation because it is in students according to their needs (Puspitarini \& Hanif, 2019). Student motivation dramatically contributes to student achievement (Chan \& Norlizah, 2018). Student motivation for male and female students is the same (Salta \& Koulougliotis, 2020). On the indicators of the desire and desire to succeed and the desire and need in learning, out of 11 students, only 3 students considered learning activities important. Most students already have this motivation on the indicators of future hopes and aspirations, but the efforts to achieve it are still not maximal. For example, students want to get good grades on a material, but their learning is still lacking. The most crucial factor is that students must take up learning activities to be motivated by these activities (Bathgate \& Schunn, 2017).

\section{Student Creative Thinking Skills}

Creative thinking skills are students' ability to use their minds to develop new ideas and discoveries in natural or abstract forms (Saptenno et al., 2019)creative thinking skills, and cognitive learning results of students of Senior High 
School 6 of Ambon, Indonesia. This research is quasi-experimental research using a non-equivalent pretest-post-test control group design. The subjects of this research were class XI Science students with a total number of 40 students. One group was taught by using the Modified Problem Based Learning (M-PBL. Creative thinking is a phenomenon that can unconsciously generate insight. The ability to think creatively is also called divergent thinking ability, which has four indicator components (Batlolona et al., 2019). Four indicators of creative thinking include (1) fluency (fluency), understood as the ability to generate multiple ideas, (2) flexibility (flexible thinking), referred to as the ability to create qualitatively diverse solutions (3) originality (original thinking), responsible for generating rare and atypical ideas and (4) elaboration (thinking in detail), is referred to as the ability to develop ideas (Jankowska et al., 2019;integrating quantitative and qualitative approaches and involving 98 five-year-old children (54 girls and 44 boys Batlolona et al., 2019). In this study, the creative thinking instrument in preparing questions refers to the four creative thinking indicators, namely fluency, flexibility, originality, and elaboration, with simple aircraft material.

Based on the analysis of students 'creative thinking abilities, the students' ability to think creatively was mostly lacking, with a percentage of $42.8 \%$ in Table 2 . Then classically, the average of each indicator is calculated, and the results show that the questions on elaboration indicators most students answered correctly. In contrast, the originality indicator (original thinking) was the least number of students answered correctly.

Table 2. Recapitulation of students' initial creative thinking abilities

\begin{tabular}{llc}
\hline Score Range & Information & $\begin{array}{c}\text { The Percent- } \\
\text { age of Student } \\
\text { Scores (\%) }\end{array}$ \\
\hline Score 0-19 & Very less & 0 \\
Score 20-39 & Less & 42,8 \\
Score 40-59 & Moderate & 28,6 \\
Score 60 -79 & Good & 14,3 \\
Score 80-100 & Very good & 14,3 \\
\hline
\end{tabular}

The elaboration indicator (thinking in detail) was mostly answered correctly by students in Table 3 because the test questions tend to be more straightforward. In the test questions, students find the force needed by someone when pushing an object into a truck. The ability to think in detail or elaboration is the ability to develop ideas, add and enrich an idea, and detail interesting facts (Batlolona et al., 2019). The originality indicator (original thinking) was the least number of students answered correctly. Students mentioned the simple type of plane when someone played badminton and chose a simple plane with less force when moving objects to a higher place. This question is still relatively easy, but students are not careful enough to answer correctly, only $14.3 \%$ of students. Original thinking ability or originality has the responsibility to produce answers or ideas that are rare, atypical, and rarely given by many people (Jankowska et al., 2019) integrating quantitative and qualitative approaches and involving 98 five-year-old children (54 girls and 44 boys. Even though the teacher has implemented a creative learning model, there is no student interest and ability, so learning is considered less successful (Saptenno et al., 2019)creative thinking skills, and cognitive learning results of students of Senior High School 6 of Ambon, Indonesia. This research is quasi-experimental research using a non-equivalent pretest-post-test control group design. The subjects of this research were class XI Science students with a total number of 40 students. One group was taught by using the Modified Problem Based Learning (MPBL.

Based on the research results, thinking creatively is still less, so applying it spurs students' creative thinking abilities. The learning environment that supports learning activities is less than optimal, leading to low learning motivation, learning outcomes, and students' creative thinking skills (Saptenno et al., 2019). Creative thinking is a positive action that can stimulate brain function and create the right learning style (Suratno et al., 2019). Learning styles can influence a person in absorbing and processing information that may affect thinking results. Students' creative thinking skills need to be improved in school by providing opportunities to students for what is on their thinking. The results of the analysis of student interviews and questionnaires show that the learning media commonly used by teachers are instructional videos, KIT, and torso on certain materials, so this is one of the factors for the lack of students' creative thinking level. Learning using comics can increase student creativity and interest in understanding the concept of learning material (Jamal et al., 2019). 
Table 3. Percentage of students' creative thinking indicators

\begin{tabular}{lccc}
\hline $\begin{array}{l}\text { Creative Think- } \\
\text { ing Indicators }\end{array}$ & $\begin{array}{c}\text { Av- } \\
\text { erage }\end{array}$ & Score & $\begin{array}{c}\text { Student An- } \\
\text { swers (\%) }\end{array}$ \\
\hline \multirow{4}{*}{ Fluency } & & 0 & 14,3 \\
& 0,46 & 2 & 14,3 \\
& & 3 & 57,1 \\
& & 4 & 14,3 \\
Fexibility & & 0 & 14,3 \\
& & 1 & 14,3 \\
& & 3 & 42,9 \\
& & 4 & 0 \\
Originality & 0,39 & 28,6 \\
& & 1 & 28,6 \\
& & 3 & 28,6 \\
& & 4 & 14,3 \\
& & 0 & 14,3 \\
Elaboration & 0,60 & 2 & 14,6 \\
& & 3 & 0 \\
& & 4 & 57,2 \\
\hline
\end{tabular}

\section{Media Development Needs}

Learning media is a tool for delivering learning material (Ntobuo et al., 2018). The use of learning media is crucial to support learning activities. Especially for vibrations, waves, and sound in everyday life, which are still considered difficult. Based on questionnaires and interviews, students had difficulty understanding the material and examples. Teachers have a problem delivering materials and examples using media suitable for vibrations, waves, and sound in everyday life. As many as $58 \%$ of students strongly agree if the material of vibrations, waves, and sounds in daily life use learning media, as shown in Figure 3 . There is a need for learning media that can provide better material delivery and understanding.

Teachers and students agree that learning on vibrations, waves, and sound in everyday life uses learning media in electronic comics, which are contained in line webtoon, as shown in Figure 4. Students like to read comics in the webtoon. If they apply electronic comics as a learning medium, they can feel happy and interested in learning. Learning using digital comics provides a positive experience for students because it is unique and 21st-century students who are considered digital natives (Mamolo, 2019). The storyline in comics presented in digital format acts as a learning medium (Ntobuo et al., 2018). Comics can also help teachers solve problems and involve students in learning (Matuk et al., 2019).

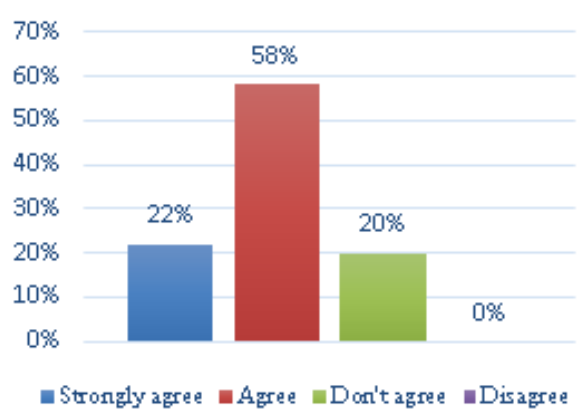

Figure 3. The material of vibrations, waves, and sounds in everyday life if conveyed by learning media

Teachers and students agree that learning on vibrations, waves, and sound in everyday life uses learning media in electronic comics, which are contained in line webtoon, as shown in Figure 4. Students like to read comics in the webtoon. If they apply electronic comics as a learning medium, they can feel happy and interested in learning. Learning using digital comics provides a positive experience for students because it is unique and 21st-century students who are considered digital natives (Mamolo, 2019). The storyline in comics presented in digital format acts as a learning medium (Ntobuo et al., 2018). Comics can also help teachers solve problems and involve students in learning (Matuk et al., 2019).

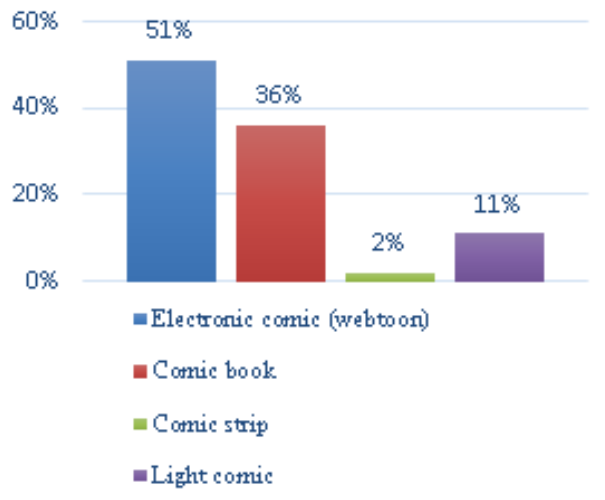

Figure 4. Comic media used in science learning

Book comics and electronic comics have several differences. Figure 5 and Figure 6 show examples of comic books and electronic comics. Comic books in the form of books that are less 
practical to carry need to be printed, thus increasing production costs. Webtoon comics are not in the form of books but electronic comics so that students can easily access them via cellphones. Webtoon comics are cost-effective, easy to store or archive and distribute, more practical to carry, and more durable than paper media. Simple comic drawings with excellent and clear characters make it easier for students to understand the messages conveyed visually.

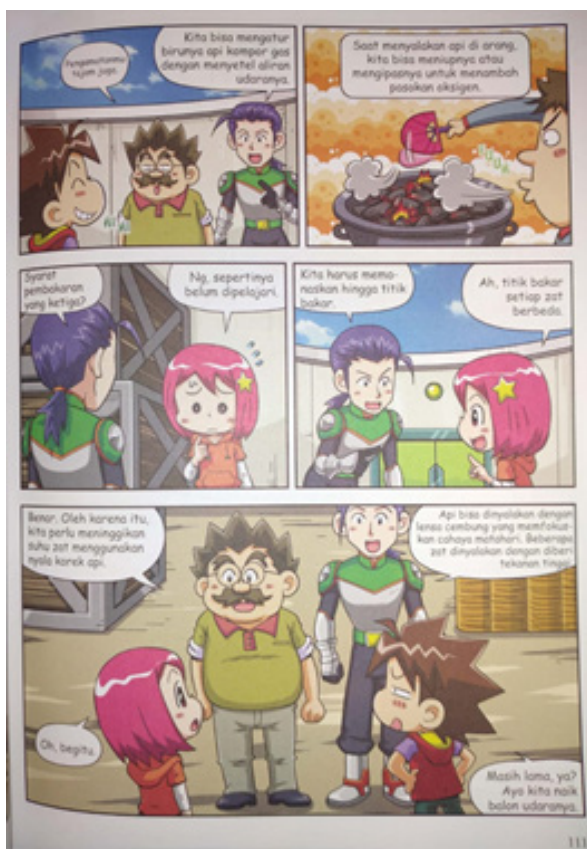

Figure 5. Comic textbook

Teachers and students also stated that electronic comic learning media based on integrated problem based learning of Islamic values is used as an alternative to learning media on vibrations, waves, and sounds in everyday life needed for development. The need for electronic comic media development is shown in Figure 7 , with a required percentage of $64 \%$. Teachers and students suggest developing electronic comic media, using everyday Indonesian, including text, examples, and colored pictures to make it easier for students to understand the story's contents and not quickly feel bored. The cover of your favorite electronic comic containing photographs and writing. Comics can help students learn efficiently and practically because they provide attractive illustrations and convey material in simple language (Lesmono et al., 2018). The addition of humor in comics helps students quickly understand the science content presented in comics (Roswati et al., 2019). Comics also can attract and motivate students to learn (Affeldt et al., 2018).
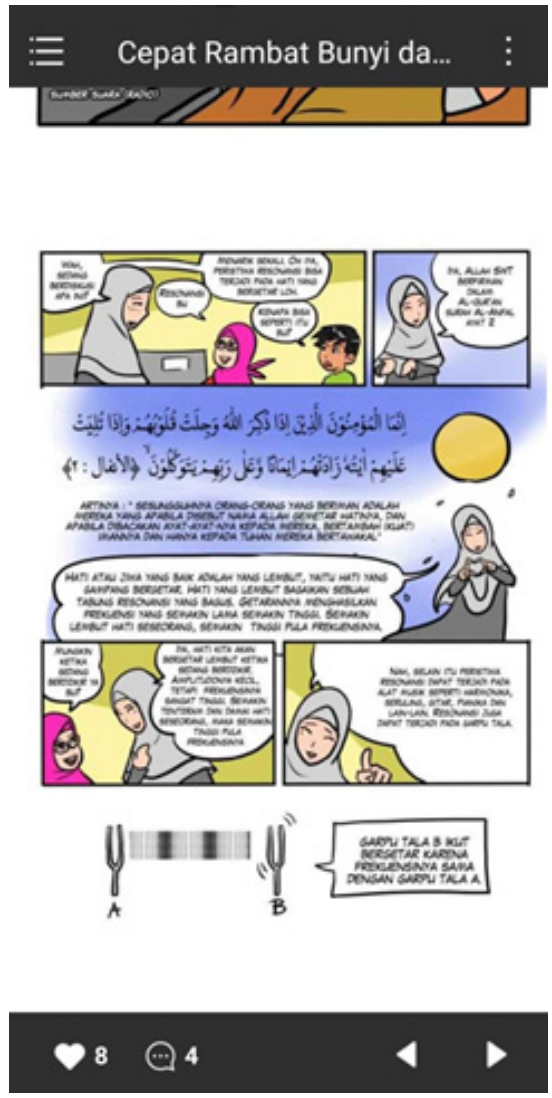

Figure 6. Comic webtoon

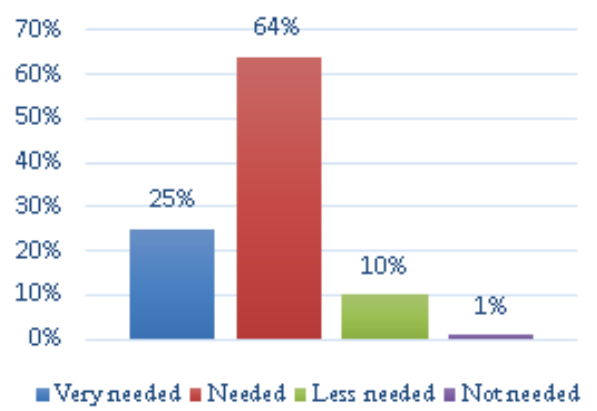

Figure 7. The need for electronic comic media development

This problem based learning integrated electronic comic with Islamic values will be presented in several episodes related to vibration, waves, and sounds in everyday life. Each episode presents problems that exist in everyday life. This electronic comic also integrates with Islamic values in al-Quran verses related to vibrations, waves, and sounds in everyday life. This preliminary study is expected to provide an alternative to learning media that teachers and students can use for the learning process. 


\section{CONCLUSION}

The questionnaire and interview analysis results show that the teacher's difficulties during learning are that students' focus is quickly lost, student motivation is lacking, and the difficulty in delivering material with the right learning media. Intrinsic motivation that exists in students is still low. Students' creative thinking skills are still lacking, with a percentage of $42.8 \%$. The elaboration indicator (thinking in detail) was mostly answered correctly by students. In contrast, on the originality indicator (original thinking), students were less careful in answering, so that only $14.3 \%$ of students could answer correctly. Based on the teacher and student questionnaire analysis results, electronic comic learning media based on problem based learning integrated Islamic values as an alternative teaching media on vibrations, waves, and sounds in everyday life needed to be developed with a percentage of $64 \%$. The learning media is expected to increase students' motivation and creative thinking skills.

\section{REFERENCES}

Affeldt, F., Meinhart, D., \& Eilks, I. (2018). The use of comics in experimental instructions in a nonformal chemistry learning context. International Journal of Education in Mathematics, Science and Technology, 6(1), 93-104.

Balim, A. G., Inel-Ekici, D., \& Ozcan, E. (2016). Concept Cartoons Supported Problem Based Learning Method in Middle School Science Classrooms. Journal of Education and Learning, 5(2), 272-284.

Bathgate, M., \& Schunn, C. (2017). The Psychological Characteristics of Experiences that Influence Science Motivation and Content Knowledge. International Journal of Science Education, 39(17), $1-29$.

Batlolona, J. R., Diantoro, M., Wartono, \& Latifah, E. (2019). Creative thinking skills students in physics on solid material elasticity. Journal of Turkish Science Education, 16(1), 48-61.

Bayrak, R., \& Gürses, A. (2020). Teaching of the Subject of Solids Through Problem-Based Learning Approach. World Journal of Education, 10(3), 47-56.

Chan, Y. L., \& Norlizah, C. H. (2018). Students' Motivation towards Science Learning and Students'TM Science Achievement. International Journal of Academic Research in Progressive Education and Development, 6(4), 174-189.

Derbel, E. (2019). Teaching Literature through Comics: An Innovative Pedagogical Tool. International Journal of Applied Linguistics and English Literature, 8(1), 54-61.

Fery, M. F., Wahyudin, \& Tatang, H. (2017). Improv- ing primary students mathematical literacy through problem based learning and direct instruction. Educational Research and Reviews, 12(4), 212-219.

Jamal, S. N. B., Ibrahim, N. H. B., \& Surif, J. Bin. (2019). Concept cartoon in problem-based learning: A systematic literature review analysis. Journal of Technology and Science Education, 9(1), 51-58.

Jankowska, D. M., Gajda, A., \& Karwowski, M. (2019). How children's creative visual imagination and creative thinking relate to their representation of space. International Journal of Science Education, 41(8), 1096-1117.

Kahraman, E., \& Koray, O. (2020). The use of standardized feedback for teaching material preparation: The opinions of preservice science teachers. Eurasian Journal of Educational Research, 2020(90), 83-102.

Kim, J., Chung, M. S., Jang, H. G., \& Chung, B. S. (2017). The use of educational comics in learning anatomy among multiple student groups. Anatomical Sciences Education, 10(1), 79-86.

Korur, F., Toker, S., \& Eryilmaz, A. (2016). Effects of the Integrated Online Advance Organizer Teaching Materials on Students' Science Achievement and Attitude. Journal of Science Education and Technology, 25(4), 628-640.

Koutníková, M. (2018). The Application of Comics in Science Education. Acta Educationis Generalis, 7(3), 88-98.

Ledbetter, B., Wallace, Z., Harms, A., Siraj, A., \& Buchanan, L. (2016). CySCom: CyberSecurity COMics Using Comics for Teaching Cybersecurity Concepts to Youth. Ieee International Conference on Intelligence and Security Informatics: Cybersecurity and Big Data, 282-284.

Lesmono, A. D., Bachtiar, R. W., Maryani, \& Muzdalifah, A. (2018). The instructional-based andro-web comics on work and energy topic for senior high school students. Jurnal Pendidikan IPA Indonesia, 7(2), 147-153.

LIbao, N. J. P., Sagun, J. J. B., Tamangan, E. A., Pattalitan, A. P., Dupa, M. E. D., \& Bautista, R. G. (2016). Science learning motivation as correlate of students' academic performances. Journal of Technology and Science Education, 6(3), 209-218.

Mamolo, L. A. (2019). Development of digital interactive math comics (DIMaC) for senior high school students in general mathematics. Cogent Education, 6(1), 1-13.

Matuk, C., Hurwich, T., Spiegel, A., \& Diamond, J. (2019). How Do Teachers Use Comics to Promote Engagement, Equity, and Diversity in Science Classrooms? Research in Science Education.

Mills, R., Tomas, L., Whiteford, C., \& Lewthwaite, B. (2020). Developing Middle School Students' Interest in Learning Science and Geology Through Slowmation. Research in Science Education, 50(4), 1501-1520.

Ntobuo, N. E., Arbie, A., \& Amali, L. N. (2018). The development of gravity comic learning media 
based on gorontalo culture. Jurnal Pendidikan IPA Indonesia, 7(2), 246-251.

Nurdyansyah, N., \& Arifin, M. B. U. B. (2018). Integration of Islamic Values in Elementary School. 125(Icigr 2017), 190-192.

Nuryantini, A. Y. (2018). Integration Science and Religion: An Analysis in Islamic Higher Education. TARBIYA: Journal of Education in Muslim Society, 5(1), 11-18.

Prins, G. T., Bulte, A. M. W., \& Pilot, A. (2018). Designing context-based teaching materials by transforming authentic scientific modelling practices in chemistry. International Journal of Science Education, 40(10), 1108-1135.

Purwati, N., Zubaidah, S., Corebima, A. D., \& Mahanal, S. (2018). Increasing Islamic Junior High School students learning outcomes through integration of science learning and Islamic values. International Journal of Instruction, 11(4), 841-854.

Puspitarini, Y. D., \& Hanif, M. (2019). Using Learning Media to Increase Learning Motivation in Elementary School. Anatolian Journal of Education, 4(2), 53-60.

Rina, N., Suminar, J. R., Damayani, N. A., \& Hafiar, H. (2020). Character Education Based on Digital Comic Media. International Journal of Interactive Mobile Technologies, 14(3), 107-127.

Ronan, L. K., \& Czerwiec, M. K. (2020). A Novel Graphic Medicine Curriculum for Resident Physicians: Boosting Empathy and Communication through Comics. Journal of Medical Humanities, 41(4), 573-578.

Roswati, N., Rustaman, N. Y., \& Nugraha, I. (2019). The Development of Science Comic in Human Digestive System Topic for Junior High School Students. Journal of Science Learning, 3(1), 1218.

Salta, K., \& Koulougliotis, D. (2020). Domain specificity of motivation: chemistry and physics learning among undergraduate students of three academic majors. International Journal of Science Education, 42(2), 253-270.
Saptenno, A. E., Tuaputty, H., Rumahlatu, D., \& Papilaya, P. M. (2019). The improvement of learning motivation and creative thinking skills of senior high school students through modified problem based learning model. Journal for the Education of Gifted Young Scientists, 7(4), 11751194.

Scavone, P., Carrasco, V., Umpiérrez, A., Morel, M., Arredondo, D., \& Amarelle, V. (2019). Microbiology can be comic. FEMS Microbiology Letters, 366(14), 1-6.

Shekarbaghani, A. (2016). Comparative Study of Physics Curriculum in Iran with Several Other Countries. International Education Studies, 9(8), 112-119.

Sudjana. (2005). Metoda Statistika. Bandung: Tarsito.

Suratno, Komaria, N., Yushardi, Dafik, \& Wicaksono, I. (2019). The effect of using synectics model on creative thinking and metacognition skills of junior high school students. International Journal of Instruction, 12(3), 133-150.

Tribull, C. M. (2017). Sequential Science: A Guide to Communication Through Comics. Annals of the Entomological Society of America, 110(5), 457-466.

Uno, H. H. B. (2016). Teori Motivasi \& Pengukurannya Analisis di Bidang Pendidikan. Jakarta: Bumi Aksara.

White, W. J. (2017). Optical Solutions: Reception of an NSF-Funded Science Comic Book on the Biology of the Eye. Technical Communication Quarterly, 26(2), 101-115.

Wood, R. (2019). Students' motivation to engage with science learning activities through the lens of self-determination theory: Results from a single-case school-based study. Eurasia Journal of Mathematics, Science and Technology Education, 15(7), 1-22.

Yew, E. H. J., \& Goh, K. (2016). Problem-Based Learning: An Overview of its Process and Impact on Learning. Health Professions Education, 2(2), 75-79. 